\title{
Complement Activation Triggers Metalloproteinases Release Inducing Cervical Remodeling and Preterm Birth in Mice
}

\author{
Juan M. Gonzalez, ${ }^{*}$ Claus-Werner Franzke, ${ }^{\dagger}$ \\ Fengyuan Yang, ${ }^{\ddagger}$ Roberto Romero, ${ }^{*}$ \\ and Guillermina Girardi ${ }^{\S}$ \\ From the Perinatology Research Branch,* National Institutes of \\ Health, National Institute of Child Health and Human \\ Development, Bethesda Maryland; the Department of \\ Dermatology, University Medical Center Freiburg, ${ }^{\dagger}$ Freiburg, \\ Germany; the Department of Chemical Engineering and Material \\ Science, and Biomedical Engineering, ${ }^{\ddagger}$ Wayne State University, \\ Detroit, Michigan; and the Department of Chemical Engineering \\ and Material Science, ${ }^{\S}$ York College, The City University of New \\ York, New York
}

Inflammation is frequently linked to preterm delivery (PTD). Here, we tested the hypothesis that complement activation plays a role in cervical remodeling and PTD. We studied two mouse models of inflammation-induced PTD. The first model was induced by vaginal administration of lipopolysaccharide (LPS) and the second one by administration of progesterone antagonist RU486. Increased cervical C3 deposition and macrophages infiltration and increased serum C3adesArg and C5adesArg levels were observed in both models when compared to gestational age matched controls. A significant increase in collagen degradation, matrix metalloproteinase 9 (MMP-9) activity and tissue distensibility was observed in the cervix in both models. Mice deficient in complement receptor C5a did not show increased MMP-9 activity and cervical remodeling and did not deliver preterm in response to LPS or RU486, suggesting a role for C5aR in the cervical changes that precede PTD. In vitro studies show that macrophages release MMP-9 in response to $\mathrm{C5a}$. Progesterone diminished the amount of $\mathrm{C5aR}$ on the macrophages surface, inhibited the release of MMP-9 and prevented PTD. In addition, macrophages depletion also prevented cervical remodeling and PTD in LPS-treated mice. Our studies show that $\mathrm{C}_{5} \mathrm{a}-\mathrm{C} 5 \mathrm{aR}$ interaction is required for MMP-9 release from macrophages, and the cervical remodeling that leads to PTD. Complement inhibition and supplementation with progesterone may be good therapeutic options to prevent this serious pregnancy complication. (Am J Pathol 2011, 179:838-849; DOI: 10.1016/j.ajpath.2011.04.024)

Premature birth/delivery (PTD) is one of the most significant causes of perinatal mortality and morbidity in developed countries. Preterm infants suffer morbidities including respiratory distress, intraventricular hemorrhage, and cerebral palsy, among other serious diseases. ${ }^{1}$ These outcomes can have a life-long impact and more than \$25 billion is spent each year to take care of these infants. Investigations to define the causes of PTD remain a challenge in the obstetrical field. Preterm labor is a multistage biochemical and biophysical process, during which changes in the myometrium and the cervix occur.

The uterine cervix is a complex organ that undergoes extensive changes through gestation and parturition. These changes are a common first step in preterm parturition. ${ }^{2}$ As a gatekeeper for pregnancy, the cervix is a structural barrier that keeps the fetus inside the uterus until the end of gestation. Collagens, elastin, proteoglycans, and hyaluronate are responsible for the full tensile strength of the cervix. ${ }^{2}$ Ripening of the cervix is an important biological and clinical event required for a normal parturition. The process is gradual during pregnancy, with a fast final remodeling of the cervix before parturition. Increased collagen degradation and synthesis, and high activity of collagenases have been observed in the human cervix during final ripening. ${ }^{3}$

Supported by the Intramural Research Program of the Eunice Kennedy Shriver National Institute of Child Health and Human Development, National Institutes of Health, Department of Health and Human Services.

Accepted for publication April 15, 2011.

None of the authors disclosed any relevant financial relationships.

Current address of G.G., The Queen's Medical Research Institute, Edinburgh.

Address reprint requests to Guillermina Girardi, Ph.D., The Queen's Medical Research Institute, 47 Little France Crescent, Edinburgh, EH16 4TY, UK. E-mail: Guillermina.Girardi@ed.ac.uk. 
Improper timing of these complex changes can result in PTD, which is a major public health problem, and there has been little reduction in its incidence during the past 40 years. ${ }^{4,5}$ This is mainly caused by our incomplete understanding of the cascade and processes that occur in the remodeling of the cervix. The characterization of the cervical changes that precede parturition in women is complicated, because it is difficult to determine antenatally which women will deliver preterm. Therefore, an animal model that best simulates the clinical scenarios should be used to investigate the mechanisms underlying cervical remodeling and PTD.

Inflammation and activation of innate immunity has been associated with preterm delivery. ${ }^{6}$ Recently, a study demonstrated that inflammatory cytokines in cervicovaginal fluid and in amniotic fluid, but not in plasma, are strongly associated with spontaneous PTD in women, suggesting that inflammation at the maternal-fetal interface, rather than systemic inflammation, may play a major role in the etiology of PTD. ${ }^{7}$ Despite the growing association between inflammation and PTD, the mediators, receptors, and cellular participants in triggering cervical changes remain unclear. Therefore, we sought to study the mechanism or mechanisms responsible for the cervical changes underlying PTD induced by localized inflammation in mice. In this study, we induced PTD in mice by intravaginal administration of lipopolysaccharide (LPS), resembling ascending infection/inflammation, which is the most common clinical situation. We also used a second mouse model of preterm parturition induced by progesterone antagonist RU486. Progesterone antagonists have been previously shown to cause infiltration of inflammatory cells into the cervical stroma in pregnant mice and women..$^{8,9}$

The complement system, an important component of innate immunity, plays a pivotal role in recruiting inflammatory and immunocompetent cells contributing to various immune and inflammatory diseases. Several complications of pregnancy, including spontaneous pregnancy losses, ${ }^{10,11}$ pre-eclampsia, ${ }^{12,13}$ and pre-term labor ${ }^{14-18}$ have been associated with a maternal complement activation. Importantly, increased activation of complement components in maternal blood and the amniotic fluid has been reported in patients with preterm delivery. ${ }^{14,17,19}$ Thus, we hypothetized that complement activation is a mediator in inflammation-induced preterm delivery in mice. The objective of the present study was to test the hypothesis that complement activation may account for the cervical changes responsible for inflammation-induced PTD in mice.

It has been reported that progesterone can reduce the rate of PTD in a high-risk population. ${ }^{20,21}$ The biological mechanisms responsible for the protective effect of progesterone remain poorly elucidated. In addition, progesterone has been suggested to have anti-inflammatory effects, ${ }^{22,23}$ and mice lacking progesterone receptor exhibit reproductive abnormalities characterized by inflammation. ${ }^{24}$ Therefore, we sought to investigate if progesterone is able to decrease or prevent inflammationinduced PTD in mice.
Identifying the immune effectors that mediate PTD might provide novel and important targets for the prevention and prediction of premature labor in women.

\section{Materials and Methods}

\section{Ethics Statement}

Our animal studies were performed by following the Russell and Burch ${ }^{25}$ "Three R's" concept of Replacement, Reduction, and Refinement to minimize animal use and pain or distress while still achieving the critical scientific objectives. All of the experiments performed were conducted in accordance with the National Institute of Health guidelines on laboratory animals and with approval from Wayne State University and York College, The City University of New York committee on Animal Use and Care.

\section{Animals}

C57BL/6 timed-pregnant mice were purchased from Jackson Laboratories (Bar Harbor, ME). Animals were shipped on days 10 to 12 after mating. Animals were acclimated in the animal facility for 3 to 5 days before use in these experiments. C5aR-deficient $(\mathrm{C} 5 \mathrm{aR}-/-)$ females and males were also purchased from Jackson Laboratories. $\mathrm{C} 5 \mathrm{aR}-1-$ females were mated with $\mathrm{C} 5 \mathrm{aR}-1-$ males in our animal facility. The presence of a vaginal plug was considered as day 0 of pregnancy.

\section{Mouse Models of Preterm Delivery}

\section{PTD Induced by LPS}

In an attempt to develop a mouse model of PTD, which resembles most clinical scenarios in that localized inflammation occurs without systemic maternal illness, we administered LPS (Escherichia coli serotype 055:B5 (250 $\mu \mathrm{g} /$ mouse, intravaginally) on day 15 of pregnancy. This model mimics a clinical or subclinical vaginal infection/ inflammation that can ascend to the cervix, the deciduas, myometrium, fetal membranes, the amniotic fluid, and thus the fetus leading to premature labor. Most of the pregnant females (94.7\%) delivered within 24 to 36 hours of LPS administration (Figure 1A). No maternal morbidity or mortality was observed in this model.

To determine whether supplementation with progesterone could prevent inflammation-induced preterm parturition, on day 15 of pregnancy the mice were randomly treated with progesterone (2 mg/mouse, s.c.; Sigma Chemicals, St Louis, MO) $(n=14)$ or an equal volume of vehicle (sunflower oil) $(n=5) 1$ hour before LPS administration.

To elucidate the role of complement receptor C5a (C5aR), C5aR-/- mice $(n=9)$ received intravaginal LPS on day 15 of pregnancy.

To deplete macrophages $300 \mu \mathrm{g}$ of anti-F4/80 (BM8; eBioscience) or isotype antibody (rat lgG2a, $\kappa$; eBioscience, San Diego, CA) was given i.p. on day 15, 4 hours before LPS injection ( $n=4$ to 6 ). This antibody was previously used successfully to deplete macrophages in pregnant mice. ${ }^{26}$ 

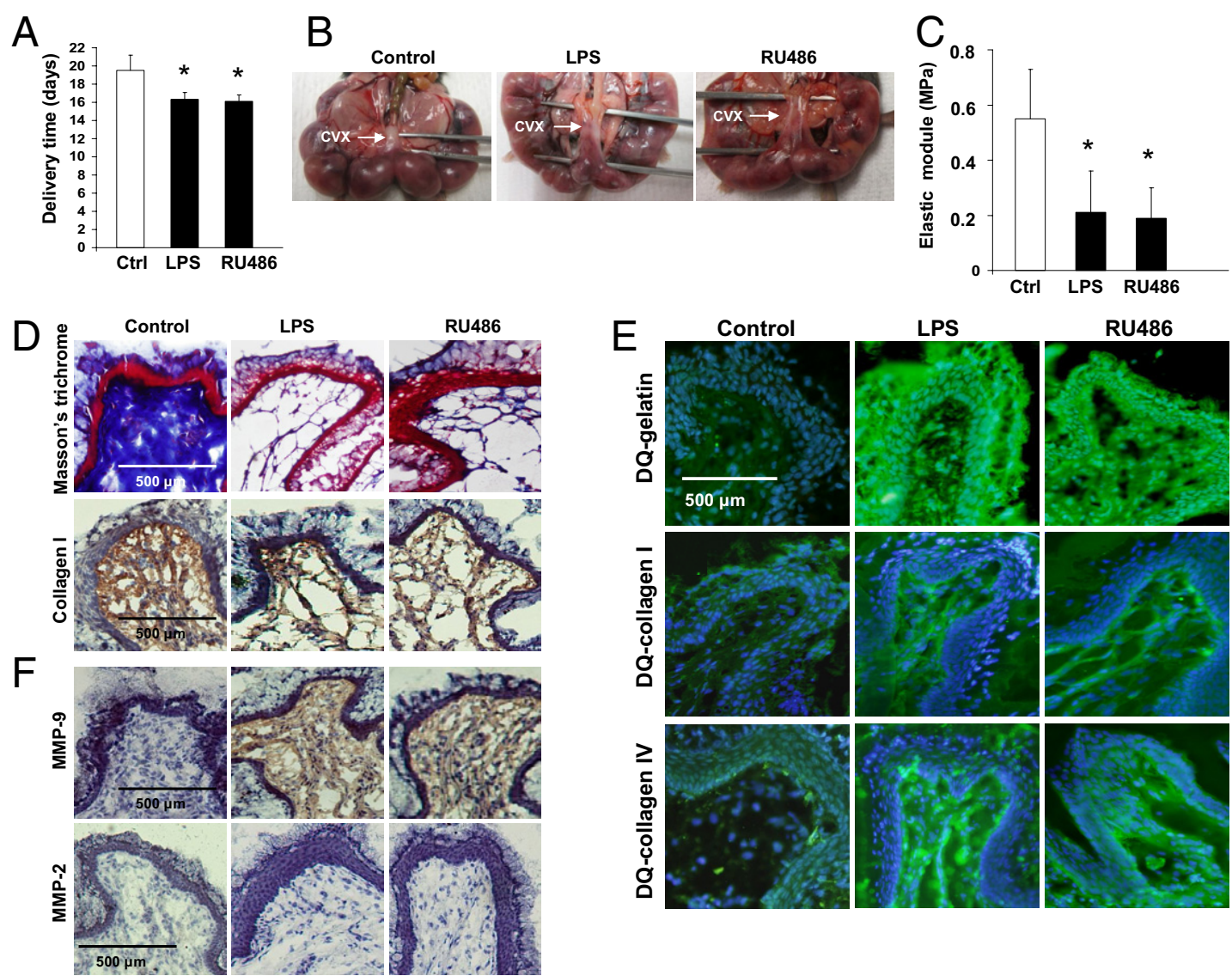

Figure 1. Cervical remodeling and preterm labor/delivery (PTD) in LPS- and RU486-mice. A: Delivery time in control and LPS- or RU486-treated mice $(n=5$ to 7 mice/group). Significantly different from control, ${ }^{*} P<0.05$. B: Gross evaluation of the cervix. Arrows identify the posterior side of the cervix. Note the increased distensibility observed in LPS- (middle panel) and RU486-treated mice (right panel) when compared to the firm and rigid cervix of control mice (left panel). C: Biomechanical studies of the cervix. The elastic modulus was decreased in the cervical tissue of LPS- and RU486-treated mice when compared to control mice, suggesting a decrease in the stiffness of the cervix in the mice that deliver preterm. D: Collagen staining. The collagen was determined by Masson's trichrome staining (upper panels) and by IHC using a specific antibody that reacts with mouse collagen type I (lower panels). Dense network of collagen fibers was observed in control cervix (left panels). Disperse thin fibers of collagen were observed in the cervix of LPS- (middle panels) and RU486-treated mice (right panels). E: In situ zymography using DQ gelatin (upper panel), DQ collagen type I (middle panel), and DQ collagen type IV (lower panel). Increased fluorescence (increased gelatin and collagen I and IV degradation) is present in the cervix of LPS- (middle panel) and RU486-treated mice (right panels). Weak fluorescence (low gelatin and collagen degradation) is observed in control cervical tissue (left panels). F: Detection of matrix metalloproteinase (MMP)-2 and MMP-9 in cervical tissues by IHC. Increased MMP-9 staining was observed in the cervix of LPS- (middle upper panel) and RU486-treated mice (right upper panel) when compared to control mice (left upper panel). On the other hand no increase in staining for MMP-2 was observed in the cervix of LPS- (middle lower panel) and RU486-treated mice (right lower panel). The weak staining for MMP-2 in these mice was comparable to control mice (left lower panel).

Mice from every experimental group were euthanized antepartum (12 to 18 hours after treatment). Blood samples and cervical tissue were collected from the mice in each experimental group. Macroscopic, biomechanical, and histological evaluation of the cervix was performed. Delivery was considered preterm if it occurred within 48 hours after LPS administration (before gestational day 17).

\section{PTD Induced by Progesterone Antagonist RU486}

In this model, PTD was induced by administration of RU486 (mifepristone, Sigma Chemicals, St. Louis, MO) (150 $\mu \mathrm{g} /$ mouse subcutaneously) $(n=6)$ dissolved in dimethyl sulfoxide, as described in the literature. ${ }^{27}$ It was previously described that RU486 increases the recruitment of immune cells to the cervix. ${ }^{8,9}$ Mice treated with RU486 give birth within 24 hours (Figure 1A). Mice were euthanized during the antepartum (12 to 18 hours after treatment) to analyze the cervical changes that precede
PTD. Gestational age-matched controls were euthanized at the same time as treated mice. Delivery was considered preterm if it occurred within 48 hours after RU486 administration (before gestational day 17).

To study the role of C5aR, C5aR-/- mice $(n=7)$ were treated with RU486 on day 15 as previously described. Mice from every experimental group were euthanized antepartum (12 to 18 hours after treatment). Gestational age-matched controls were euthanized at the same time as treated mice. Blood samples and cervical tissue were collected from mice in each experimental group. Macroscopic, biomechanical, and histological evaluation of the cervix was performed.

\section{Serum C3adesArg and C5adesArg Levels}

To determine whether complement activation occurs in LPS and RU486-treated mice that deliver preterm, generation of complement split products $\mathrm{C} 3 \mathrm{a}$ and $\mathrm{C} 5$ a were 
measured by the more stable metabolites C3adesArg and C5adesArg. The C3adesArg in serum was measured by sandwich enzyme-linked immunosorbent assay (ELISA) using rat anti-mouse $\mathrm{C} 3 \mathrm{a}$ and biotin rat antimouse C3a. Both antibodies were purchased from BD Biosciences Pharmingen (San Diego, CA). A Standard curve was performed using purified mouse C3a protein (native) (BD Biosciences Pharmingen). C5adesArg was also measured by sandwich ELISA using rat anti-mouse C5a and biotin rat anti-mouse C5a. Both antibodies and mouse purified $\mathrm{C} 5 \mathrm{a}$ protein for the standard curve were purchased from BD Biosciences.

To determine whether LPS treatment diminished progesterone levels in mice, antepartum serum progesterone was measured by Enzyme Immune assay (Cayman Chemicals, Ann Arbor, MI).

\section{Tissue Biomechanics}

The stiffness of the cervix was evaluated by measuring the elastic modulus. The cervix were excised longitudinally and mounted to tensile testing equipment with a calibrated mechanical drive attached to a force transducer (Com-Ten, Pinellas Park, FL). The length of the cervix was increased isometrically in 10-mm increments per minute. The amount of force required to distend the cervix and the tension exerted by the stretched tissue were recorded. The length was increased until either forces exerted by the tissue reached a plateau or the tissue tore. Force was plotted as a function of cervical length. The slope of the linear portion of the force-strain curve was computed as an index of tissue stiffness and elasticity (elastic modulus). A steeper slope indicates increased resistance to stretch, and therefore decreased elasticity (elastic modulus). The data were recorded using data acquisition Com-Ten software.

\section{Immunohistochemistry and Immunocytochemistry}

For immunohistochemical studies, cervical tissues were frozen in OCT compound, and cut into 10- $\mu \mathrm{m}$ sections. These sections were stained for $\mathrm{C} 3$ with rabbit antimouse C3 (2 $\mu \mathrm{g} / \mathrm{mL}$; LifeSpan Biosciences, Seattle, WA), neutrophils were stained with rat anti-mouse granulocyte RB6-8C5 mAb (5 $\mu \mathrm{g} / \mathrm{mL}$; BD Biosciences Pharmingen), and macrophages were stained with F4/80 $(10 \mu \mathrm{g} / \mathrm{mL}$; Novus Biologicals Inc, Littleton, CO). Matrix metalloproteinase (MMP)-9 was detected in frozen cervical sections using a rabbit polyclonal anti-mouse MMP-9 antibody (10 $\mu \mathrm{g} / \mathrm{mL}$; Abcam, Cambridge, MA). MMP-2 was detected in using a rabbit polyclonal anti-mouse MMP-2 antibody (3 $\mu \mathrm{g} / \mathrm{mL}$; Abcam, Cambridge, MA). Collagen I distribution was determined using a polyclonal antibody against collagen type I (10 $\mu \mathrm{g} / \mathrm{mL}$; ACRIS Antibodies, $\mathrm{GmbH}$, Herford, Germany). Horseradish peroxidase-labeled specific secondary antibodies and 3,3'-diaminobenzidine as substrate were used to develop the respective reactions.

Masson's Trichrome staining was also performed to detect collagen fibers distribution in cervical frozen sections. The collagen fibers stained blue and the background stained red. Four slides per animal were stained and 6 to 8 animals were studied in each experimental group.

\section{In Situ Zymography}

MMP-9 activity and MMP-2 activity were measured by in situ zymography as previously described. ${ }^{28}$ Briefly, 10$\mu \mathrm{m}$-cervix sections were washed in PBS and then incubated for 2 hours in $20 \mu \mathrm{g} / \mathrm{mL}$ DQ-labeled gelatin, DQcollagen I, or DQ collagen IV (Invitrogen, Carlsbad, CA) in $50 \mathrm{mmol} / \mathrm{L} \mathrm{Tris}-\mathrm{HCl}, 50 \mathrm{mmol} / \mathrm{L} \mathrm{NaCl}, 10 \mathrm{mmol} / \mathrm{L} \mathrm{CaCl}_{2}$, $\mathrm{pH} 6.8$ at $37^{\circ} \mathrm{C}$ in the dark. In parallel, control sections were pre-incubated with buffer containing $10 \mathrm{mmol} / \mathrm{L}$ EDTA followed by 2-hour incubation in DQ-gelatin or DQcollagen solution supplemented with $10 \mathrm{mmol} / \mathrm{L}$ EDTA to indicate the contribution of metalloproteinases. The reaction was stopped by removing the substrate solution followed by 10 minutes incubation in $4 \%$ paraformaldehyde PBS. Finally, mounting medium supplemented with DAPI (Vector Laboratories, Burlingame, CA) was applied. Sections were observed under a fluorescence microscope (Nikon Eclipse 50i; Nikon Inc., Melville, NY) and photographs were taken using a Nikon DigiSight Color Digital Camera System and NIS-Elements Research Imaging Software. Increased fluorescence indicates increased gelatin and collagen degradation by MMPs. Each experimental group consisted of 6 to 9 mice and four tissue sections per animal were studied.

\section{Preparation of Cervical Tissue Lysates for Gelatin Zymography}

Cervical tissues were dissected immediately after euthanasia, and $1 \mathrm{~g}$ of tissue was homogenized in $1 \mathrm{~mL}$ of lysis buffer consisting of $0.1 \mathrm{M}$ Tris- $\mathrm{HCl}, \mathrm{pH} 6.8,1 \mathrm{M}$ urea, $1 \%$ nonyl phenoxypolyethoxylethanol (NP)-40, $10 \mathrm{mmol} / \mathrm{L}$ EDTA, $1 \mathrm{mmol} / \mathrm{L}$ 4-(2-aminoethyl) benzenesulfonyl fluoride (AEBSF), and proteinase-inhibitor mix, using a homogenizer. All lysates were centrifuged at $15,000 \mathrm{~g}$ for 30 minutes, and colorimetric protein detection was performed in the supernatants using the BCATM Protein assay kit (Pierce, Rockford, IL). Samples of equal protein content $(25 \mu \mathrm{g})$ were mixed with fivefold concentrated Laemmli buffer separated by electrophoresis on 10\% SDS-polyacrylamide gels containing $0.8 \mathrm{mg} / \mathrm{mL}$ gelatin in a nonreducing condition. After electrophoresis, the gel was rinsed twice for 10 minutes in $2.5 \%$ Triton-X-100 to wash off the SDS and rinsed twice for 10 minutes in water to remove Triton-X-100. The gel was then incubated with an incubation buffer containing $1 \%$ Tween $20,10 \mathrm{mmol}$ $\mathrm{CaCl}_{2}, 1 \mu \mathrm{mol} \mathrm{ZnCl}_{2}$, and $50 \mathrm{mmol}$ Tris-Cl $(\mathrm{pH} 7.5)$ at $37^{\circ} \mathrm{C}$ for 18 hours, and stained with Bio-Safe Coomassie Stain solution (Bio-Rad, Hercules, CA). Purified ProMMP-9 (R\&D Systems, Minneapolis, MN) was used for identification. Three independent experiments with different mice were performed. 


\section{Production of MMP-9 Proenzyme in Vitro}

Splenocytes from C57BL/6 female mice were incubated for 12 and 24 hours in culture medium supplemented with $10 \%$ inactivated fetal bovine serum. Nonadherent cells were removed and adherent cells (>95\% peroxidase-positive) were incubated in culture medium supplemented with $10 \%$ inactivated fetal bovine serum, with the addition of the following stimuli: none (control); C5a (10 nmol/L); C5a (10 $\mathrm{nmol} / \mathrm{L})$ plus progesterone (10 nmol/L). After 12 and 24 hours, culture supernatants were collected and analyzed for MMP-9 proenzyme by ELISA (R\&D Systems).

A group of macrophages was incubated on slides with increasing concentrations of progesterone (10, 20, and $40 \mathrm{nmol} / \mathrm{L}$ ). After 12 hours incubation, macrophages were tested for C5aR synthesis by RT-PCR and expression by $\mathrm{IHC}$. For $\mathrm{IHC}$, cells were fixed in $5 \%$ paraformaldehyde and stained with anti-C5aR antibody $(20 \mu \mathrm{g} / \mathrm{mL}$ Hycult Biotech; Cell Sciences Inc., Canton, MA) followed by secondary antibody labeled with horseradish peroxidase. Some macrophages were permeabilized before staining with Tween 20 (0.5\%). The histochemical reaction was developed with DAB. The DAB staining was quantified using the NIS-Elements Research Imaging software (Nikon Inc. Tech Co., Ltd., Tokyo, Japan). Exposure time was fixed and the camera settings were kept constant. The macrophages were segmented based on $\mathrm{red} / \mathrm{green} / \mathrm{blue}$ intensity, and the area was restricted to eliminate debris. Measurements data per object were calculated using the following parameters: sum density (the sum of individual optical densities of each pixel in the area being measured) and mean density (statistical mean of density values of pixels). NIS-Elements BR (Nikon Inc., Tokyo, Japan) uses density calibration curves for evaluation of these parameters. There were 25 macrophages per slide that were analyzed in each experimental condition.

\section{Quantitative RT-PCR}

To determine whether C5a differentially regulated the expression of MMP-9 in macrophages, we studied the synthesis of MMP-9. RNA was harvested from macrophages with RNeasy Mini Kit (Qiagen, Valencia, CA) and $1 \mu \mathrm{g}$ of total RNA was reverse transcribed. Relative quantification of gene expression was performed by real-time PCR using The Biomark System (Fluidigm San Francisco, CA). Primer sequences mouse glyceraldehydes-3-phosphate dehydrogenase and mouse MMP-9 were obtained from Applied Biosystems (Foster City, CA). Relative expression was normalized for levels of GAPDH. The generation of only the correct size amplification products was confirmed using agarose gel electrophoresis.

To investigate the effects of progesterone on C5aR expression in macrophages, we also performed qRTPCR as previously described. The primers for C5aR were also obtained from Applied Biosystems (Foster City, CA).

\section{Statistical Analysis}

Data are expressed as mean $\pm \mathrm{SD}$. After confirming that the data were normally distributed (Kolomogorov-Smirnov test of normalcy), statistical analyses were conducted using Student's $t$-test to compare differences in means. Associations were considered to be statistically significant if the value of $P<0.05$. Data were processed using SigmaStat (version 3.1), statistical program for Windows.

\section{Results}

\section{Collagen Degradation in Cervical Remodeling Induced by LPS and RU486}

Mice treated with LPS or RU486 delivered preterm. Parturition in these mice occurred before gestational day 17 (Figure $1 \mathrm{~A}$ ). To elucidate the mechanism responsible for PTD, we investigated if remodeling of the cervix occurs in these mice.

Collagen I and III are the predominant component of the cervix extracellular matrix and gives tensile strength to it. ${ }^{2}$ Collagenases of the MMP family degrade collagen softening of the cervix (in a process called cervical remodeling) and prepare it for dilation and delivery. ${ }^{3}$ Macroscopic examination of the cervix in LPS- and RU486-treated mice (Figure 1B) antepartum showed increased distensibility and elasticity when compared to firm and rigid cervix observed in gestational age match controls (Figure 1B, left panel). Biomechanical studies of the cervix confirmed these results. The slope of the ascendant part of the regression line of the stress-strain curve (elastic modulus) was decreased in the cervical tissue of LPS- and RU486-treated mice when compared to control mice, suggesting a decrease in the stiffness of the cervix in mice that deliver preterm (Figure 1C). Masson's trichrome (TC) staining revealed a decreased number of collagen fibers in the cervix of mice treated with LPS or RU486 antepartum (Figure 1D, middle and right upper panels) when compared to the high density of collagen fibers observed in control mice (Figure 1D, left upper panel). Immunohistochemical studies with specific antibodies against mouse collagen I showed a similar distribution pattern to the TC staining (Figure 1D, lower panels). Collagen packing was disorganized, collagen fibers looked thinner, and greater spacing between fibers were observed in LPS- and RU486-treated mice (Figure 1D, middle and right lower panels) when compared to age-matched controls (Figure 1D, left lower panel).

Decreased density in collagen fibers was associated with increased cervical MMP activity (Figure 1E). In situ zymography using DQ gelatin and DQ collagen I and IV as substrate revealed an increase in activity of MMPs with gelatinolytic and collagenolytic activity in the cervix of mice treated with LPS or RU486 (Figure 1E). Collagen is degraded by the sequential action of many MMPs to gelatin, and subsequently gelatin is degraded by MMPs. Both MMP-9 and MMP-2 have the capacity to cleave collagen I, collagen IV, and gelatin. ${ }^{29}$ Robust MMP activity (green fluorescence) was observed in the cervix of LPSand RU486-treated mice incubated with $D Q$ gelatin and $D Q$ 
collagen I and IV (Figure 1E) in contrast with the weak fluorescence (diminished MMP activity) observed in the cervix of control mice (Figure 1E, left panels). Taken together, these data suggest that MMP-9 and/or MMP-2 might be responsible for the degradation of the cervical matrix during antepartum, decreasing cervical tensile strength, and leading to PTD in LPS- and RU486-treated mice.

Immunohistochemical studies identified MMP-9 as the main collagenase involved in cervical remodeling in LPSand RU486-treated mice that deliver preterm. Increased MMP-9 staining (Figure 1F, middle and right upper panels), but not MMP-2 (Figure 1F, middle and right lower panels) was observed in the stroma and epithelium of mice with inflammation-induced preterm birth compared to agematched controls (Figure 1F, upper and lower right panels).

\section{Complement Activation in LPS- and RU486-Treated Mice}

Knowing that complement activation plays a crucial role in many pregnancy complications, we investigated if complement activation is a mediator in the pathogenesis of the cervical changes that lead to PTD in LPS- and RU486-treated mice. In accordance with our hypothesis, increased C3 deposition was observed in the cervical columnar epithelium in LPS- and RU486-treated mice (Figure 2A) when compared to gestational age-matched controls (Figure 2A). In addition, increased C3adesArg levels were measured in serum of LPS- and RU486treated mice during antepartum compared to control mice (Figure 2B). Complement split product C5adesArg was also increased in LPS- and RU486-treated mice when compared to controls (Figure 2C).

\section{Inflammatory Cells in the Cervical Tissue}

It has been suggested that inflammatory cells play an important role in the cervical changes before delivery at term. Thus, we investigated if inflammatory cells are present during cervical remodeling in preterm delivery induced by LPS and RU486. Immunohistochemical studies with anti-F480 antibodies showed increased macro-
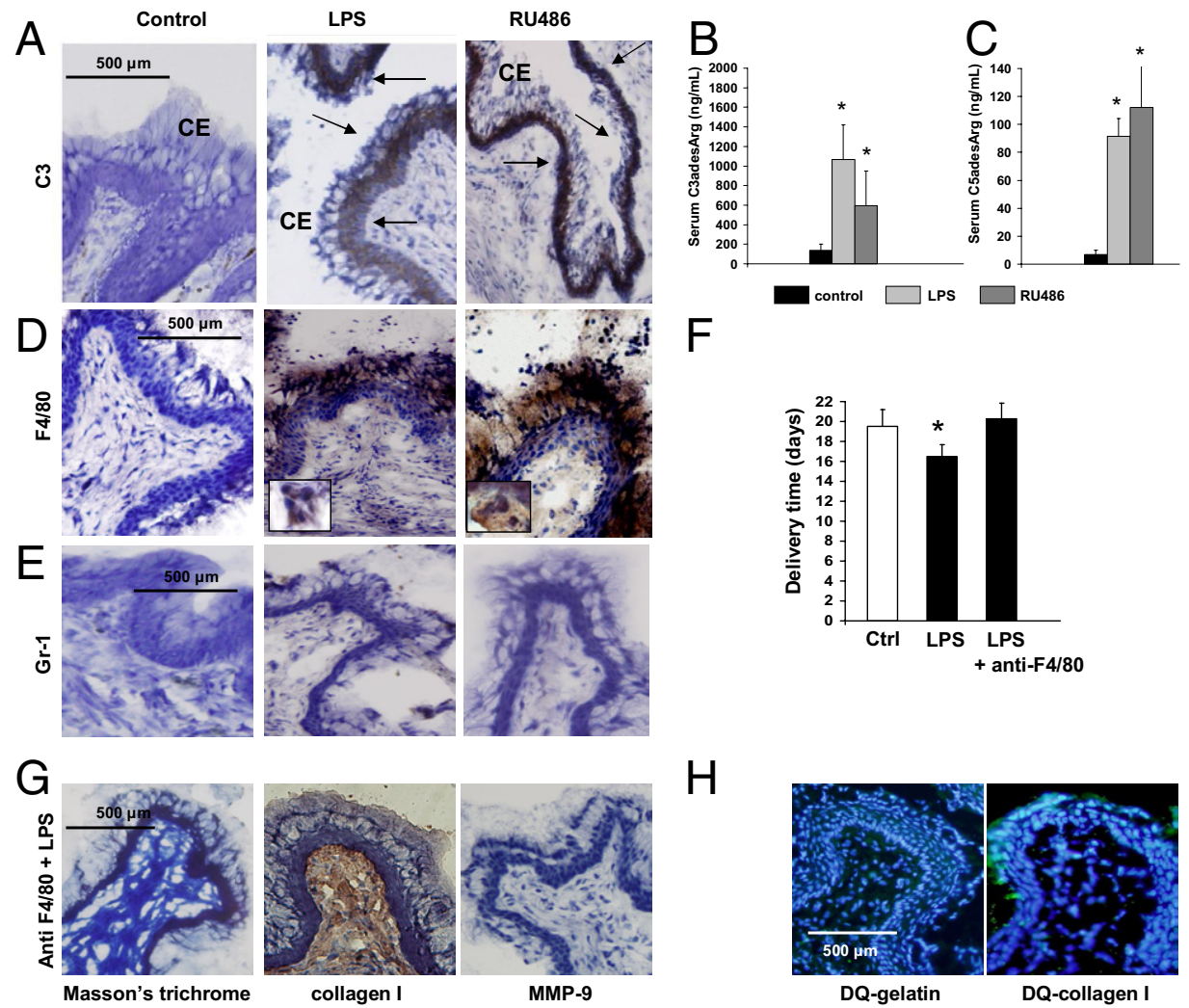

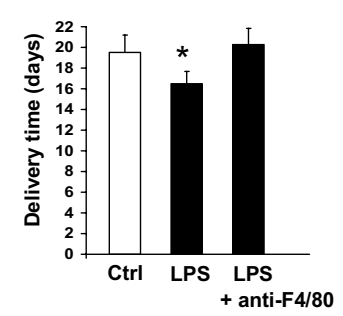

$\mathrm{H}$

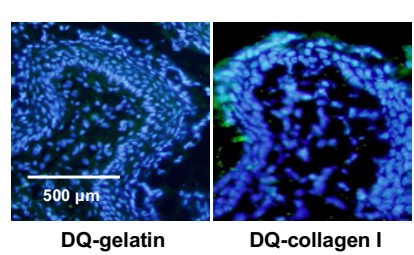

Figure 2. Complement activation and macrophages/monocytes infiltration in the cervix of LPS- and RU486-treated mice. A: Immunohistochemical determination of C3 in cervical tissue. Arrows indicate C3 deposition (brown staining) in the columnar epithelium (CE) in LPS- (middle panel) and RU486-treated mice (right panel). No complement deposition was observed in the cervical tissue of the control mice (left panel). Original magnification is $\times 20$. B: Serum C3adesArglevels in control, LPS-, and RU486-treated mice. Statistically different from control, ${ }^{*} P<0.05$ ( $n=5$ to 6 mice/group). C: Serum C5adesArglevels in control, LPS-, and RU486-treated mice. Statistically different from control, ${ }^{*} P<0.05$ ( $n=5-6$ mice/group). D: F4/80 staining in cervical tissue. Increased macrophage infiltration (brown color) was observed in the cervical stroma, epithelium, and mucus of LPS- (middle panel) and RU486-treated mice (right panel). Few macrophages were observed in the cervix of age-matched control mice (left panel). Original magnification is $\times 20$. The inserts in the middle and right panels include macrophages shown at a higher magnification. E: Gr-1 staining in cervical tissue. Few Gr-1+ neutrophils cells were found in the cervical stroma of control (left panel), LPS(middle panel), and RU486-treated mice (right panel). Original magnification is $\times 20$. F: Delivery time in control, LPS-, and LPS plus anti-F4/80 ( $n=4-6$ mice/group). Significantly different from control, ${ }^{*} P<0.05$. G: Trichrome (TC) staining for collagen I and for matrix metalloproteinase (MMP)-9 in cervical tissue of LPS-treated mice depleted of macrophages with anti-F4/80. Abundant collagen fibers were shown with TC staining (left panel) and by IHC with antibodies against collagen I (middle panel). Staining for MMP-9 was negative in F480 plus LPS-treated mice (right panel). H: $I n$ situ zymography using DQ-gelatin and DQ-collagen I as substrate in LPS-treated mice pretreated with anti-F4/80. Gelatin and collagen I degradation was not observed in cervical tissue from F4/80 plus LPS-treated mice. Original magnification is $\times 20$. 
phages infiltration in the cervical stroma, epithelium, and mucus in LPS- and RU486-treated mice compared to gestational age-matched controls (Figure 2D). The presence of macrophages in the cervix of mice that deliver preterm suggests that macrophages may be involved in the cervical changes that precede PTD.

Few positive Gr-1 cells were observed in the cervix of control, LPS- and RU486-treated mice (Figure 2E) suggesting that neutrophils might not be involved in the cervical remodeling that precedes PTD in LPS- and RU486-treated mice.

\section{Macrophages Depletion Prevents PTD in LPS-Treated Mice}

To examine the relative importance of macrophages in LPS-induced cervical changes and preterm delivery, we depleted macrophages by treating mice with anti-F4/80 antibodies. In the absence of macrophages, treatment with LPS did not cause preterm birth (Figure 2F) nor were there inflammatory infiltrates in the cervix (data not shown). Furthermore, without macrophages infiltration there was less collagen degradation, as shown in Figure $2 \mathrm{G}$ in which $\mathrm{TC}$ staining and $\mathrm{IHC}$ with anti-collagen I antibodies showed a dense network of collagen fibers comparable to control mice (Figure 1D). Decreased MMP-9 activity (Figure 2G) and decreased proteolytic activity against gelatin and collagen I (Figure $2 \mathrm{H}$ ) was also observed in LPS-treated mice depleted of macrophages. Diminished collagen degradation and MMP-9 activity suggest that macrophages may play a role in cervical remodeling that leads to PTD in LPS-treated mice. LPS-treated mice that received isotype control antibody delivered within 24 to 36 hours (data not shown).
A
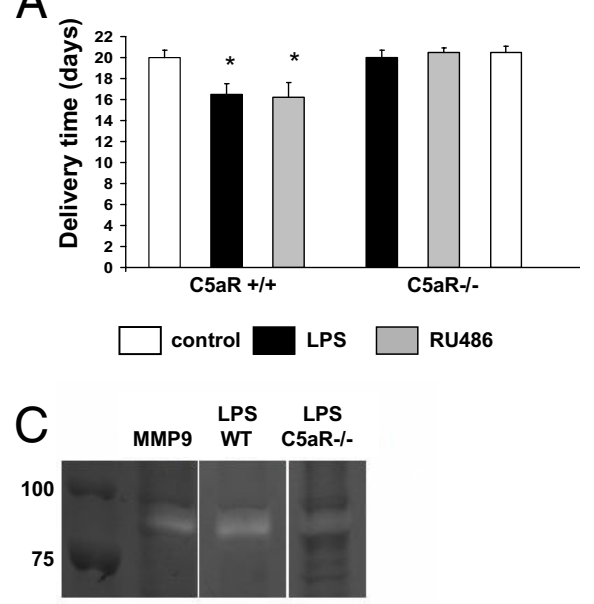

E

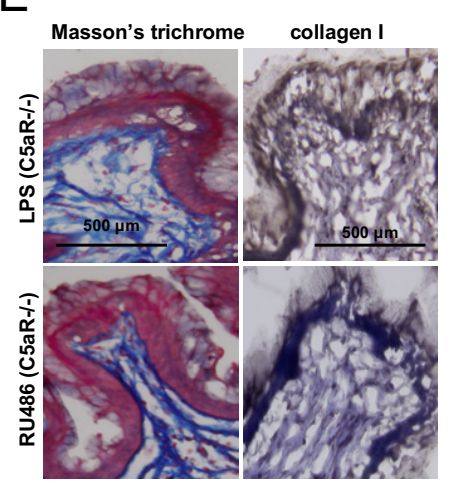

$\mathrm{B}$

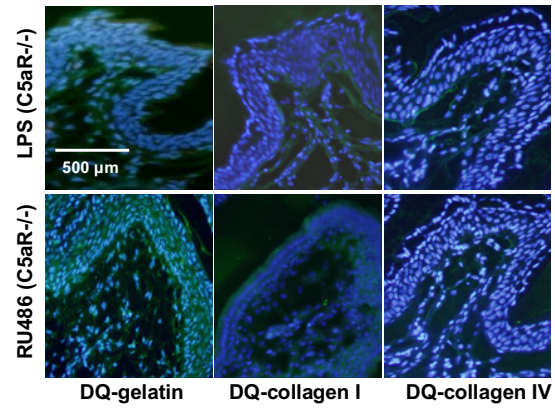

$\mathrm{D}$

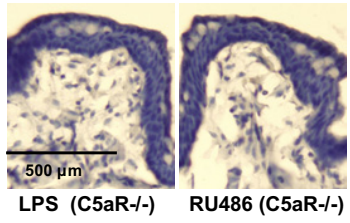

$\mathrm{F}$

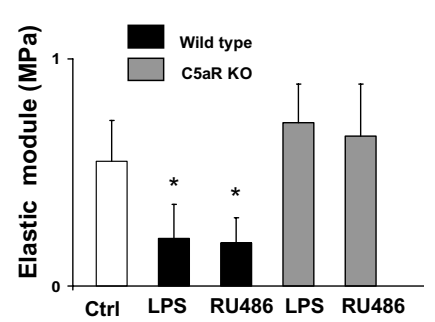

G

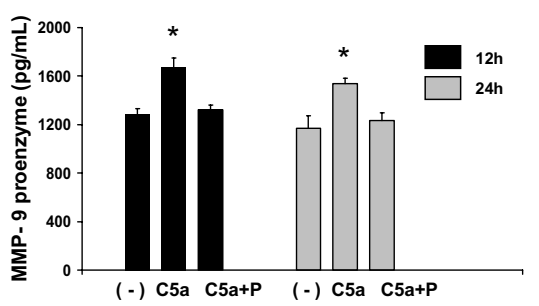

Figure 3. C5aR deficiency and progesterone prevents preterm labor/delivery (PTD). A: Delivery time in control and LPS- or RU486-treated, wild-type, C5aR+/+ and $C 5 a R-/-$ mice ( $n=5$ to 7 mice/group). Significantly different from control, ${ }^{*} P<0.05$. B: In situ zymography using DQ gelatin (left panels), DQ collagen I (middle panels), and DQ collagen IV (right panels). In contrast to the increased fluorescence (increased gelatin and collagen degradation) observed in the cervix of LPS- (Figure 1E, middle panels) and RU486-, wild-type treated mice (Figure 1E, right panels), gelatin and collagen degradation was not observed in LPS(upper panels) and RU486-treated, C5aR-/- mice (lower panels) comparable to control cervical tissue (Figure 1E, left panels). C: Gel zymography of nonreduced cervical tissue lysates. Purified matrix metalloproteinase (MMP)-9 was used as a control. Increased MMP-9 was observed in wild-type (WT) mice treated with LPS. D: Immunohistochemical detection of MMP-9 revealed weak staining for MMP-9 in LPS- (left panel) and RU486-treated, C5aR-/- mice (right panel). E: Collagen detection by trichrome staining and IHC. Dense network of collagen fibers was observed in the cervix of LPS- (upper panels) and RU486-treated (lower panels) C5aR-/- mice in contrast with the disperse thin fibers of collagen observed in the cervix of LPS- and RU486-treated, wild-type, C5aR $+/+$ mice (Figure 1D, middle and right panels, respectively). F: Biomechanical studies of the cervix. The elastic modulus (measure of the tissue stiffness) was decreased in the cervical tissue of LPS- and RU486-, wild-type treated mice when compared to control mice. Decreased elastic module was not observed in LPS- and RU486-treated C5aR-/- mice, indicating an increase in the stiffness of the cervix in these mice. Elastic module values in LPS- and RU486-treated mice were comparable to age-matched control mice $\left(n=4\right.$ mice/group). Significantly different from control mice (Ctrl), ${ }^{*} P<0.05$. G: Complement activation triggers release of pro-MMP-9 by murine macrophages in vitro. Splenic macrophages were stimulated with C5a and C5a plus progesterone (P). Culture supernatants were collected after 12 and 24 hours and analyzed for MMP-9 by enzyme-linked immunosorbent assay ( $n=4$ experiments/group; ${ }^{*} P<0.05$ versus untreated cells). 


\section{C5a and C5aR Interaction Is a Critical Mediator} of LPS- and RU486-Induced Preterm Delivery

Because receptors for anaphylotoxin $\mathrm{C5a}(\mathrm{C} 5 \mathrm{aR})$ are widely expressed in inflammatory cells and endothelial cells among others, ${ }^{30,31}$ we hypothesized that C5a and C5aR interactions mediate cervical remodeling and PTD in LPS- and RU486-treated mice. To test this hypothesis we performed studies in $\mathrm{C} 5 \mathrm{aR}-/-$ mice. Untreated C5aR-/- (control) mice have normal pregnancies and give birth at day 20 to day 21, similar to $\mathrm{C} 5 \mathrm{aR}+/+$, wild-type mice (Figure 3A). In wild-type, $\mathrm{C}^{2} \mathrm{aR}{ }^{+/+}$mice, LPS, and RU48-induced PTD (Figure 3A). Neither LPS nor RU486 treatment induced PTD in C5aR ${ }^{-1-}$ mice (Figure $3 \mathrm{~A}$ ). Increased MMP activity observed in LPS- and RU486-treated, wild-type, C5aR+/+ mice (Figure 1E) was not observed in C5aR-/- mice (Figure 3B). Gelatin zymography confirmed these results (Figure 3C). A diminution in MMP-9 activity was observed in the cervix of LPS-treated, C5aR-/- mice (Figure 3C, lane 4) when compared to wild-type, $\mathrm{C} 5 \mathrm{a} R+/+$ mice (Figure 3C, lane 3). Staining for MMP-9 was negative in cervical tissue from LPS- (Figure 3D, left panel) and RU486-treated mice (Figure 3D, right panel). As expected, the absence of MMP9 expression and activity in LPS- or RU486-treated, C5aR-/- mice (Figure 3, B and D) was correlated with diminished collagen degradation. Abundant collagen fibers were observed in the cervix of LPS- (Figure 3E, upper panels) and RU486-treated, C5aR-/- mice (Figure 3E, lower panels). The histological studies correlated with the biomechanical studies of the cervix. Decreased distensibility (increased elastic module) values were observed in the cervix of C5aR-/- mice treated with LPS or RU486 when compared to wild-type mice (Figure 3F). These data suggest that $\mathrm{C} 5 \mathrm{aR}$ is required for preterm cervical remodeling and PTD in LPS- and RU486-treated in mice.

\section{C5a Induces the Release of MMP-9 from Macrophages - Inhibitory Effect of Progesterone}

The importance of $\mathrm{C} 5 \mathrm{a}$ and $\mathrm{C5aR}$ interaction, the increased MMP-9 activity, and the crucial role of macrophages observed in LPS- and RU486-induced cervical changes lead us to investigate a shared mechanism of these mediators conducing to preterm delivery. We hypothesized that MMP-9 is released from macrophages in response to $\mathrm{C} 5 \mathrm{a}$. To test this hypothesis, we incubated mouse macrophages with $\mathrm{C5a}$. In agreement with our hypothesis, we found that $\mathrm{C5a}$ increased the release of MMP-9 from macrophages after 12 and 24 hours of incubation (Figure 3G). RT-PCR studies demonstrated that the increased release of MMP-9 induced by C5a was not associated with an increase in MMP-9 mRNA (false discovery rate $\mu 0.1$, fold change $>1.5$ ). These findings suggest that C5a does not affect the synthesis of MMP-9 but stimulates the release.

It has been reported that progesterone suppresses the induction of MMP-9 in the cervix in rabbits. ${ }^{32}$ Thus, we examined whether progesterone suppresses the C5a-me- diated production of MMP-9 in macrophages in culture. Supplementation of the culture media with progesterone inhibits the release of MMP-9 induced by C5a (Figure 3G). As shown in Figure 3G, the presence of progesterone C5a did not increase MMP-9 release from macrophages.

\section{Progesterone Prevents Cervical Remodeling and PTD in LPS-Treated Mice}

As progesterone withdrawal has been related with PTD, we measured progesterone levels in LPS-treated mice. We found that serum progesterone levels in LPS-treated mice antepartum were not different from age-matched control mice (42 $\pm 7 \mathrm{ng} / \mathrm{mL}$ in LPS-treated mice $(n=6)$ versus $39 \pm 6 \mathrm{ng} / \mathrm{mL}$ in control mice $(n=7)$. Because some studies reported that progesterone and $17 \mathrm{OH}$ hydroprogesterone caproate can reduce the rate of PTD in patients ${ }^{20,21}$ and because progesterone inhibits the release of MMP-9 from macrophages in our mouse model, we investigated if progesterone prevented PTD in LPS-treated mice. Pretreatment with progesterone completely reduced the incidence of inflammation-induced PTD in LPS-treated mice (Figure 4A). Mice treated with progesterone and LPS delivered at a time not different from control untreated mice (Figure 4A). The cervical changes induced by LPS were not observed in mice pretreated with progesterone. Neither increased MMP activity (Figure 4B) nor increased collagen degradation (Figure 4C) was observed in LPStreated mice pretreated with progesterone. In addition, progesterone prevented MMP-9 increase in cervical tissue in LPS-treated mice (Figure 4C). Interestingly, diminished macrophages infiltration was observed in the cervix of LPS plus progesterone-treated mice (Figure 4D), suggesting an anti-inflammatory effect of progesterone. Biomechanical studies performed in cervical tissue from LPS plus progesterone-treated mice showed increased elastic module values (increased stiffness) when compared to mice treated only with LPS (Figure 4E), suggesting that progesterone prevents inflammation-induced cervical remodeling in LPS-treated mice.

\section{Progesterone Diminishes the Expression of C5aR in the Surface of Macrophages}

Progesterone prevented inflammation-induced cervical remodeling and PTD in LPS-treated mice. Thus, progesterone would need to have anti-inflammatory effects to be able to effectively reduce the incidence of PTD. We hypothesized that the anti-inflammatory effect of progesterone observed in our studies is due to the down-regulation of C5aR on macrophages. Decreased staining for C5aR was observed in macrophages incubated with progesterone (Figure 4F). The amount of C5aR expressed on the surface of macrophages diminished with increasing doses of progesterone (Figure 4F). Decreased expression of C5aR was not associated with decreased synthesis of C5aR. RT-PCR studies showed comparable levels of $\mathrm{C} 5 \mathrm{aR}$ message in macrophages incubated with or without progesterone (false discovery rate $<0.1$, fold 
A

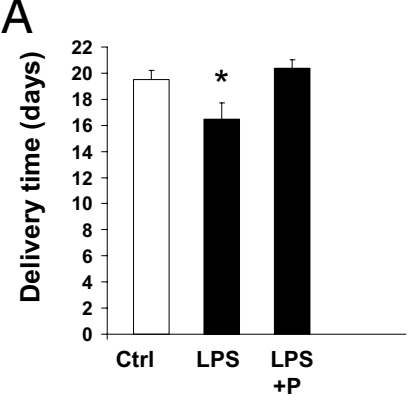

B
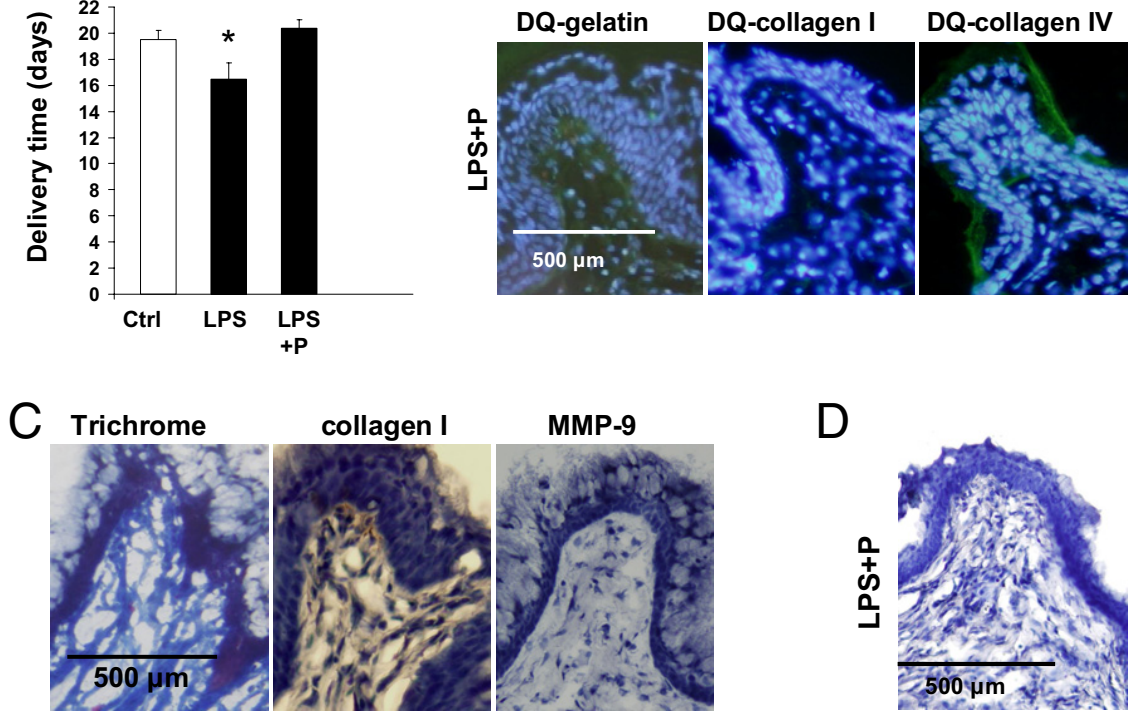

$\mathrm{E}$

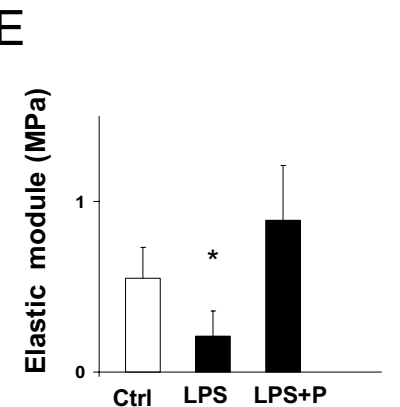

F .

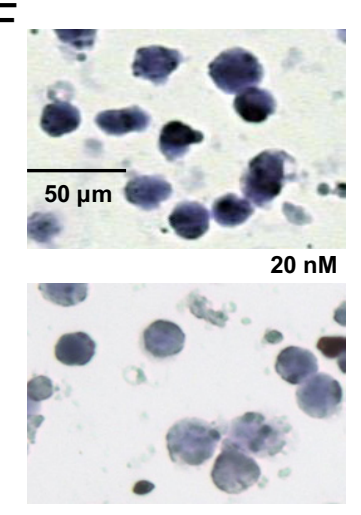

D

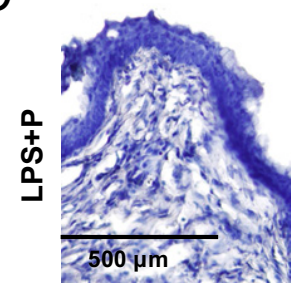

$10 \mathrm{nM}$

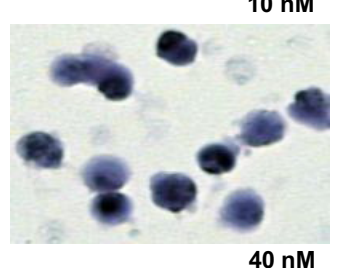

$40 \mathrm{nM}$

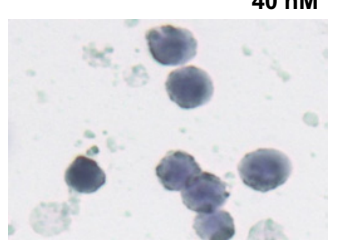

G

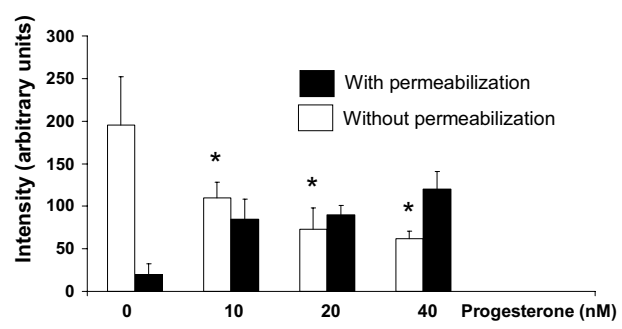

Figure 4. Progesterone (P) prevents preterm labor/delivery (PTD) in mice. A: Delivery time in control, LPS, and LPS plus P-treated mice ( $n=5$ to $7 \mathrm{mice} /$ group). Significantly different from control, ${ }^{*} P<0.05$. Note that progesterone prevents PTD in LPS-treated mice. B: Histological studies. In situ zymography using DQ gelatin, DQ collagen I, and DQ collagen IV in the cervix of LPS plus P-treated mice. Decreased degradation of gelatin and collagen was observed in LPS plus P-treated mice when compared to LPStreated mice (Figure 1E, middle panels). C: Staining for collagen in cervical tissue from LPS plus P-treated mice showed increased density of collagen fibers (left and middle panels) when compared to LPS-treated mice (Figure 1D, middle panels). Increased staining for MMP-9 observed in the cervix of LPS-treated mice (Figure $1 \mathrm{~F}$, upper middle panel) was not observed when mice were supplemented with progesterone (right panel). D: Negative staining for F $4 / 80$ in LPS plus P-treated mice. E: Biomechanical studies of the cervix. The elastic modulus (measure of the tissue stiffness) was decreased in the cervical tissue of LPS-treated mice when compared to control mice. Decreased elastic module was not observed in LPS-treated mice treated with P, indicating an increase in the stiffness of the cervical tissue in these mice. Elastic module values in LPS plus P-treated mice were comparable to age-matched control untreated mice ( $n=3$ to 4 mice/group). Significantly different from control mice (Ctrl), ${ }^{*} P<0.05$. F: Immunocytochemical detection of C5aR on murine cultured macrophages incubated without $\mathrm{P}$ and increasing doses of progesterone: $10 \mathrm{mmol} / \mathrm{L}, 20 \mathrm{mmol} / \mathrm{L}$, and $40 \mathrm{mmol} / \mathrm{L}$. G: Computerized quantification of C5aR staining on macrophages. Decreased staining for $\mathrm{C} 5 \mathrm{aR}$ was observed in macrophages incubated with increasing doses of progesterone (white bars). Increased staining was observed in permeabilized cells (black bars) suggesting that C5aR is localized intracellularly in macrophages incubated with progesterone. Significantly different from control, ${ }^{*} P<0.05$. change $>1.5$ ). When macrophages were permeabilized before staining for C5aR, positive staining for C5aR in the cytoplasm was observed (Figure 4G). A positive correlation was observed between cytoplasmic staining for C5aR and increasing doses of progesterone (Figure 4G). This data suggests that progesterone induces the internalization of $\mathrm{C} 5 \mathrm{aR}$ and thus diminishes the release of MMP-9, preventing cervical remodeling and PTD.

\section{Discussion}

We have shown by using two mouse models of preterm delivery induced by inflammation that complement activation plays an essential and causative role in the cervical structural changes that leads to preterm par- turition. These studies identified complement split product $\mathrm{C} 5 \mathrm{a}$ and macrophages as crucial mediators in the preterm birth.

In both mouse models of PTD, increased macrophages infiltration was observed in the cervical tissue, confirming the role of inflammation in PTD induced by LPS or RU486. The PTD model induced by RU486 was originally described as a model induced by progesterone withdrawal, ${ }^{27}$ but it is now known that recruitment of immune cells that remodel the cervix is a crucial feature in the mechanism responsible for preterm birth in this model. ${ }^{8,9}$ Our results showing increased cervical macrophages infiltration and increased C3a and C5a plasma levels clearly indicate that inflammation occurs in RU486 and LPS-treated mice that deliver preterm. 
Collagen is the main component of the cervical stroma. These proteins are rigid and nonextensible, and thus are responsible for the mechanical properties of the cervix. Throughout pregnancy collagenases slowly remodel (socalled softening and ripening) the collagen matrix in preparation for labor and delivery. In both models of PTD, extensive collagen degradation and decreased cervical stiffness occur, suggesting that these cervical changes are responsible for early delivery induced by inflammation.

Using histochemical and zymography techniques, we identified MMP-9 as a crucial metalloproteinase involved in the premature cervical remodeling observed in LPSand RU486-treated mice. MMP-9 not only degrades gelatin, it is also a collagenase with the capacity to cleave collagen I, III, and IV. ${ }^{29}$ Degradation of collagen fibers and disorganized collagen packing with greater spacing between fibers was observed in the cervix in LPS- and RU486-treated mice antepartum. By digesting collagen and gelatin, MMP-9 weakens the collagen matrix and thus the cervix dilates and PTD occurs.

We hypothesized that inflammation caused by LPS or RU486 creates pathological changes that accelerate the normal progress of events that lead to delivery. Thus, we investigated if inflammatory cells play a role in the cervical changes that lead to PTD induced in LPS- or RU486treated mice. We found increased macrophages, but not neutrophils, infiltrating the cervical tissue in mice that deliver preterm. Depletion of macrophages abrogated cervical ripening and rescued pregnancies to term in LPS-treated mice, confirming the crucial role of macrophages in this model of PTD.

Complement activation has been related with many inflammation-mediated pregnancy disorders in mice and humans. ${ }^{11,33}$ Increased C3a and C5a plasma levels were observed in the antepartum in mice treated with LPS or RU486 that deliver preterm. C5a is a potent chemotactic factor and activator of macrophages. Indeed, we found that macrophages release MMP-9 in response to C5a and thus are an important source of MMPs.

In vivo studies confirmed the role of $\mathrm{C} 5 \mathrm{a}$ and $\mathrm{C} 5 \mathrm{aR}$ in the premature cervical remodeling and delivery in LPS- or RU486-treated mice. LPS- or RU486-treated, C5aR-/mice showed collagen fibers densely packed and low metalloproteinase activity in the cervix. All these features are consistent with nondistensible cervixes and pregnancies that will go to term. Indeed, PTD was not observed in LPS- or RU4786-treated C5aR-/- mice. We also need to consider the possible contribution of cervical fibroblasts to the release of MMPs and the onset of PTD. ${ }^{34}$ The absence of C5aR mRNA described in human cervical cancer TC-1 cells, ${ }^{35}$ suggest that cervical cells do not express C5aR. However, cervical fibroblasts can also amplify MMPs release by a complement independent pathway.

Collectively our study demonstrates that LPS ascends from the vagina to the cervix, where the complement cascade is activated. C3b is deposited on the cervical epithelium and complement split product $\mathrm{C} 5 \mathrm{a}$ is generated. C5a attracts and activated macrophages to the cervical stroma. In response to C5a, macrophages release MMP-9 that digests collagen leading to cervical remodeling and preterm birth (Figure 5).

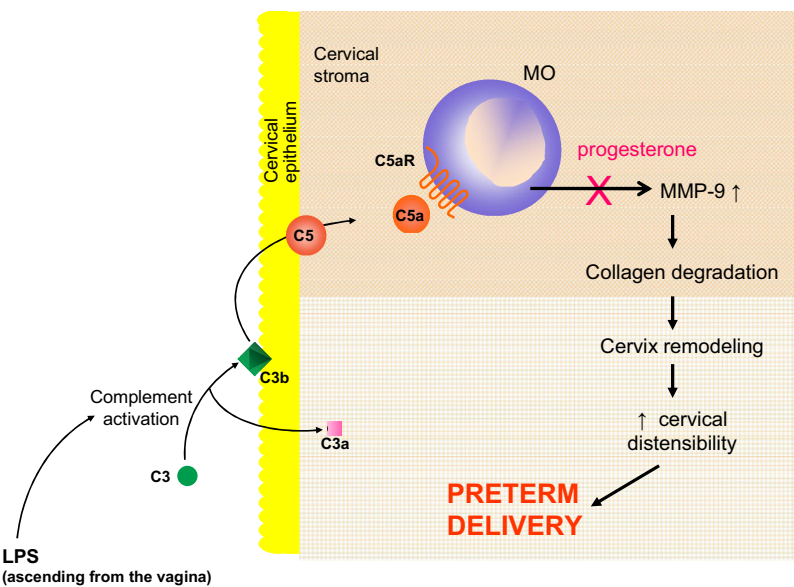

Figure 5. Proposed mechanism for LPS-induced cervical remodeling and preterm birth. LPS ascends from the vagina to the cervix, where the complement cascade is activated. C3b is deposited on the cervical epithelium and complement split product $\mathrm{C} 5 \mathrm{a}$ is generated. $\mathrm{C} 5 \mathrm{a}$ attracts and activated macrophages to the cervical stroma. In response to $\mathrm{C} 5$ a macrophages release matrix metalloproteinase (MMP)-9 that digests collagen leading to cervical remodeling, increased cervical distensibility, and preterm birth.

Based on the beneficial effects of progesterone in some human studies ${ }^{20,21}$ and on the anti-inflammatory effects of progesterone, ${ }^{23,36}$ we investigated if progesterone supplementation could prevent cervical remodeling and preterm birth in mice treated with LPS. Our studies demonstrated that progesterone pretreatment abrogated the cervical changes that lead to PTD in LPStreated mice. Neither increased MMPs activity nor collagen degradation and loss of tensile strength was observed in the cervixes of LPS-treated mice that received progesterone. In addition, progesterone inhibited C5ainduced release of MMP-9 from macrophages in vitro. C5aR expression was reduced on the surface of macrophages incubated with progesterone in comparison to those incubated with only media suggesting that decreased C5aR might contribute to the inhibitory effect of progesterone on MMPs release. However, when macrophages incubated with progesterone were permeabilized before staining, C5aR was clearly detectable in the cytoplasm of macrophages. This data suggests that $\mathrm{C} 5 \mathrm{aR}$ is internalized in macrophages incubated with progesterone. Internalization of C5aR (as many other G-coupled receptors) has been described in neutrophils and macrophages in mice and may account for diminished activity observed in these cells. ${ }^{37,38}$ Internalization of C5aR by progesterone can also explain the diminished macrophage infiltration observed in LPS plus P-treated mice. This observation is supported by the findings of Timmons and Mahendroo. ${ }^{8}$

The protective effects of progesterone in PTD can also be caused by the inhibitory effects of progesterone on MMP-9 synthesis. It has been reported that progesterone inhibits MMP-9 synthesis in rabbit uterine cervi ${ }^{32}$ and ischemic brains in rats. ${ }^{39}$ However, we did not find decreased MMP-9 mRNA in macrophages incubated with progesterone, but we found decreased release of MMP-9. Internalization of $\mathrm{C} 5 \mathrm{aR}$ on macrophages and consequent diminished cell activation by C5a may ex- 
plain the diminished release of MMP-9 from macrophages incubated with progesterone. The fact that progesterone prevents premature birth in the mouse model of LPS-induced PTD that showed no diminution in serum progesterone levels suggests that progesterone is acting as an anti-inflammatory molecule. Moreover, progesterone diminished macrophages infiltration in cervical tissue in LPS-treated mice. Several studies support the concept that progesterone has anti-inflammatory properties. ${ }^{36,40}$ Progesterone suppresses estrogen-induced C3 expression in the mouse oviducts and uterus. ${ }^{41}$ Another report showed that progesterone suppresses the complementmediated attack to allogenic chick embryos. ${ }^{42}$ Thus, we also need to consider that progesterone may prevent PTD in LPS-induced PTD by modulating the expression and/or activation of complement components.

Our studies showed the effectiveness of progesterone in preventing LPS-induced cervical remodeling. However, we also need to consider that progesterone may also contribute to the prevention of PTD by promoting uterine quiescence. Several studies demonstrated that progesterone promotes myometrial relaxation. ${ }^{43-45}$

Our finding that the absence of C5aR prevents PTD in the mouse models has important therapeutic implications. Blocking the complement cascade at C5a and $\mathrm{CaR}$ interaction inhibits mediators and effectors of cervical remodeling and prevents $\mathrm{PTD}$, suggesting that complement might be a good target for therapy in women with PTD. One of the few current treatments for women at risk of preterm labor is progesterone, which can diminish the expression of C5aR on the surface of macrophages and thus prevent inflammation, the release of MMPs, and cervical remodeling, reinforcing the idea that the complement system is a promising target for therapy in this serious pregnancy complication. Complement inhibitors are now being tested in patients with inflammatory, ischemic, and autoimmune diseases. Identifying complement-related markers that predict high risk for PTD will allow us design interventions that prevent or arrest this pathological process, which compromises the survival of the neonates born prematurely.

\section{References}

1. Iams JD, Berghella V: Care for women with prior preterm birth. Am J Obstet Gynecol 2010, 203:89-100

2. Word RA, Li X-H: Cervical function during pregnancy and parturition in preterm birth: mechanisms, mediators, prediction, preventions and interventions. Edited by Petraglia F. London, Informa Healthcare, 2007, pp 19-34 d

3. Stygar D, Wang H, Vladic YS, Ekman G, Eriksson H, Sahlin L: Increased level of matrix metalloproteinases 2 and 9 in the ripening process of the human cervix. Biol Reprod 2002, 67:889-94

4. Steer P: The epidemiology of preterm labour. BJOG 2005, 112:1-3

5. Hamilton BE, Martin JA, Ventura SJ: Births: preliminary data for 2005 Natl Vital Stat Rep 2006, 55:1-18

6. Yoon BH, Romero R, Moon JB, Shim SS, Kim M, Kim G, Jun JK Clinical significance of intra-amniotic inflammation in patients with preterm labor and intact membranes. Am J Obstet Gynecol 2001 185:1130-1136

7. Wei SQ, Fraser W, Luo ZC: Inflammatory cytokines and spontaneous preterm birth in asymptomatic women: a systematic review. Obstet Gynecol 2010, 116:393-401
8. Timmons BC Mahendroo MS: Timing of neutrophil activation and expression of proinflammatory markers do not support a role for neutrophils in cervical ripening in the mouse. Biol Reprod 2006, 74:236-245

9. Denison FC, Riley SC, Elliott CL, Kelly RW, Calder AA, Critchley HO: The effect of mifepristone administration on leukocyte populations, matrix metalloproteinases and inflammatory mediators in the first trimester cervix. Mol Hum Reprod 2000, 6:541-8

10. Girardi G, Yarilin D, Thurman JM, Holers VM, Salmon JE: Complement activation induces dysregulation of angiogenic factors and causes fetal rejection and growth restriction. J Exp Med 2006, 203:21652175

11. Girardi G, Berman J, Redecha P, Spruce L, Thurman JM, Kraus D, Hollmann TJ, Casali P, Caroll MC, Wetsel RA, Lambris JD, Holers VM, Salmon JE: Complement C5a receptors and neutrophils mediate fetal injury in the antiphospholipid syndrome. J Clin Invest 2003, 112: 1644-1654

12. Haeger M, Unander M, Bengtsson A: Complement activation in relation to development of preeclampsia. Obstet Gynecol 1991, 78: 46-49

13. Derzsy Z, Prohászka Z, Rigó J Jr., Füst G, Molvarec A: Activation of the complement system in normal pregnancy and preeclampsia. Mol Immunol 2010, 47:1500-1506

14. Lynch AM, Gibbs RS, Murphy JR, Byers T, Neville MC: Complement activation fragment $\mathrm{Bb}$ in early pregnancy and spontaneous preterm birth. Am J Obstet Gynecol 2008, 199:354-358

15. Romero R, Mazor M, Munoz H, Gomez R, Galasso M, Sherer DM: The preterm labor syndrome. Ann NY Acad Sci 1994, 734:414-429

16. Romero R, Espinoza J, Kusanovic JP, Gotsch F, Hassan S, Erez O, Chaiworapongsa T, Mazor M: The preterm parturition syndrome. BJOG 2006, 113:17-42

17. Elimian A, Figueroa R, Canterino J, Verma U, Aguero-Rosenfeld M, Tejani N: Amniotic fluid complement C3 as a marker of intra-amniotic infection. Obstet Gynecol 1998, 92:72-76

18. Vaisbuch E, Romero R, Erez O, Mazaki-Tovi S, Kusanovic JP, Soto E, Gotsch F, Dong Z, Chaiworapongsa T, Kim SK, Mittal P, Pacora P, Yeo L, Hassan SS: Fragment Bb in amniotic fluid: evidence for complement activation by the alternative pathway in women with intraamniotic infection/inflammation. J Matern Fetal Neonatal Med 2009, 22:905-916

19. Soto E, Romero R, Richani K, Espinoza J, Nien JK, Chaiworapongsa T, Santolaya-Forgas J, Edwin SS, Mazor M: Anaphylatoxins in preterm and term labor. J Perinat Med 2005, 33:306-313

20. Fonseca EB, Celik E, Parra M, Singh M, Nicolaides KH: Progesterone and the risk of preterm birth among women with a short cervix. N Engl J Med 2007, 357:462-469

21. Meis PJ, Klebanoff M, Thom E, Dombrowski MP, Sibai B: Prevention of recurrent preterm delivery by 17 alpha-hydroxyprogesterone caproate. N Engl J Med 2003, 348:2379-2385

22. Elovitz MA, Gonzalez J: Medroxyprogesterone acetate modulates the immune response in the uterus, cervix and placenta in a mouse model of preterm birth. J Matern Fetal Neonatal Med 2008, 21 : 223-230

23. Hardy DB, Janowski BA, Corey DR, Mendelson CR: Progesterone receptor plays a major antiinflammatory role in human myometrial cells by antagonism of nuclear factor-kappa B activation of cyclooxygenase 2 expression. Mol Endocrinol 2006, 20:2724-2733

24. Lydon JP, DeMayo FJ, Funk CR, Mani SK, Hughes AR, Montgomery CA Jr., Shyamala G, Conneely OM, O'Malley BW: Mice lacking progesterone receptors exhibit pleiotropic reproductive abnormnalities. Genes Dev 1995, 15:2266-2278

25. Russell WMS, Burch RL: The principles of humane experimental technique. London, Methuen \& Co., Ltd, 1959

26. Thaxton JE, Romero R, Sharma S: TLR9 activation coupled to IL-10 deficiency induces adverse pregnancy outcomes. J Immunol 2009 , 183:1144-1154

27. Dudley DJ, Branch DW, Edwin SS, Mitchell MD: Induction of preterm birth in mice by RU486. Biol Reprod 1996, 55:992-995

28. Tveita AA, Rekvig OP, Zykova SN: Increased glomerular matrix metalloproteinase activity in murine lupus nephritis. Kidney Int 2008 $74: 1150-1158$

29. Bigg HF, Rowan AD, Barker MD, Cawston TE: Activity of matrix metalloproteinase-9 against native collagen types I and III. FEBS J 2007, 274:1246-1255 
30. Czermak BJ, Sarma V, Bless NM, Schmal H, Friedl HP, Ward PA: In vitro and in vivo dependency of chemokine generation on $\mathrm{C} 5 \mathrm{a}$ and TNF-alpha. J Immunol 1999, 162:2321-2325

31. Laudes IJ, Chu JC, Huber-Lang M, Guo RF, Riedemann NC, Sarma JV, Mahdi F, Murphy HS, Speyer C, Lu KT, Lambris JD, Zetoune FS, Ward PA: Expression and function of $\mathrm{C} 5$ a receptor in mouse microvascular endothelial cells. J Immunol 2002, 169:5962-5970

32. Imada K, Ito A, Sato T, Namiki M, Nagase H, Mori Y: Hormona regulation of matrix metalloproteinase 9/gelatinase $B$ gene expression in rabbit uterine cervical fibroblasts. Biol Reprod 1997, 56 : 575-580

33. Soto E, Romero R, Richani K, Yoon BH, Chaiworapongsa T, Vaisbuch E, Mittal P, Erez O, Gotsch F, Mazor M, Kusanovic JP: Evidence for complement activation in the amniotic fluid of women with spontaneous preterm labor and intra-amniotic infection. J Matern Fetal Neonatal Med 2009, 22:983-992

34. Sato T, Ito A, Mori Y, Yamashita K, Hayakawa T, Nagase H: Hormona regulation of collagenolysis in uterine cervical fibroblasts. Biochem $J$ 1991, 275:645-650

35. Markiewski MM, DeAngelis RA, Benencia F, Ricklin-Lichtsteiner SK, Koutoulaki A, Gerard C, Coukos G, Lambris JD: Modulation of the antitumor immune response by complement. Nat Immunol 2008 , 9:1225-1235

36. Hughes GC, Martin D, Zhang K, Hudkins KL, Alpers CE, Clark EA, Elkon KB: Decrease in glomerulonephritis and Th1-associated autoantibody production after progesterone treatment in NZB/NZW mice. Arthritis Rheum 2009, 60:1775-1784

37. Guo RF, Riedemann NC, Bernacki KD, Sarma VJ, Laudes IJ, Reuben JS, Younkin EM, Neff TA, Paulauskis JD, Zetoune FS, Ward PA:
Neutrophil C5a receptor and the outcome in a rat model of sepsis. FASEB J 2003, 17:1889-1891

38. Guo RF, Riedemann NC, Sun L, Gao H, Shi KX, Reuben JS, Sarma VJ, Zetoune FS, Ward PA: Divergent signaling pathways in phagocytic cells during sepsis. J Immunol 2006, 177:1306-1313

39. Ishrat T, Sayeed I, Atif F, Hua F, Stein DG: Progesterone and allopregnanolone attenuate blood-brain barrier dysfunction following permanent focal ischemia by regulating the expression of matrix metalloproteinases. Exp Neurol 2010, 226:183-90

40. McMaster MT, Teng CT, Dey SK, Andrews GK: Lactoferrin in the mouse uterus: analyses of the preimplantation period and regulation by ovarian steroids. Mol Endocrinol 1992, 6:101-111

41. Lee YL, Cheong AW, Chow WN, Lee KF, Yeung WS: Regulation of complement-3 protein expression in human and mouse oviducts. Mol Reprod Dev 2009, 76:301-308

42. Nováková $P$, Zeman M: Progesterone inhibits embryotoxic effect of the complement system. Neuro Endocrinol Lett 1999, 20: 105-108

43. Minorics R, Gáspár R, Gál A, Klukovits A, Falkay G: Progesterone decreases the relaxing effect of the beta3-adrenergic receptor agonist BRL 37344 in the pregnant rat myometrium. Reproduction 2009, 138:383-390

44. Mesiano S, Welsh TN: Steroid hormone control of myometrial contractility and parturition. Semin Cell Dev Biol 2007, 18:321-331

45. Ruddock NK, Shi SQ, Jain S, Moore G, Hankins GD, Romero R, Garfield RE: Progesterone, but not 17-alpha-hydroxyprogesterone caproate, inhibits human myometrial contractions. Am J Obstet Gynecol 2008, 199:391.e1-e7 